\title{
JOHN JAMES MEIKLE AND THE PROBLEM OF THE WRONGLY \\ CONVICTED: AN ENQUIRY INTO THE HISTORY OF CRIMINAL APPEALS IN NEW ZEALAND
}

\author{
Jeremy Finn*
}

\begin{abstract}
This article investigates the development of the law governing of appeals in criminal cases in New Zealand, and the substantial though neglected history of agitation for recourse for the wrongly convicted. It uses as a lens the story of John James Meikle, a farmer convicted of sheep stealing in 1887, who later successfully prosecuted the principal prosecution witness for perjury, successfully petitioned Parliament for compensation, was the subject of a Royal Commission into his conviction and, uniquely, was declared innocent by an Act of Parliament in 1908. Meikle's case was one of several highly publicised cases in the period 1880-1910 which demonstrated serious shortcomings in the law and led to parliamentary and public calls for reform. By 1910, calls for enactment of legislation on the lines of the Court of Criminal Appeal (established 1907) received wide supporting in parliament and from the judiciary. The article concludes by looking at the reasons why, despite this level of consensus, reform legislation was delayed until 1945.
\end{abstract}

\section{INTRODUCTION}

This article investigates the history of appeals in criminal cases in New Zealand, and the long, and virtually, forgotten history of agitation for recourse for the wrongly convicted, using as a lens the story of John James Meikle, a farmer convicted of sheep stealing in 1887. Meikle later successfully prosecuted the principal prosecution witness for perjury, successfully petitioned Parliament for compensation, was the subject of a Royal Commission into his conviction and, uniquely, was declared innocent by an Act of Parliament, the Meikle Acquittal Act 1908. ${ }^{1}$

* Professor of Law, University of Canterbury.

1 Meikle's story has been sketched by J Findlay McArthur ("Meikle, John James 1844/1845?-1937" (2007) Dictionary of New Zealand Biography <www.dnzb.govt.nz> [DNZB]) but there has been no extended study 
Meikle's case was one of several highly publicised cases in the period 1880-1910 which demonstrated serious shortcomings in the legislation providing for criminal appeals, as is also discussed. Public and parliamentary calls for change were given further impetus by the institution of the Court of Criminal Appeal in England in 1907. Despite factors favouring change, the Criminal Code Act 1893 provisions governing appeals from jury verdicts remained largely unchanged until 1945. It has been generally assumed that New Zealand law followed English reforms but only after substantial and unexplained delay. ${ }^{2}$ This article explores these issues and suggests a major reason for that delay may have been a perception, generated by Meikle's case, that broadening the basis for appeals would lead to more frequent claims for, and disputes over, compensation for successful appellants.

\section{CRIMINAL APPEALS BEFORE 1893 AND THE CRIMINAL CODE ACT}

Until the enactment of the Criminal Code Act 1893 appellate intervention in criminal matters was limited to matters of law. It was virtually impossible to challenge a jury verdict. If the guilty verdict was perverse, or some later development indicated that it had been wrong, the only remedies were those within the discretion of the Executive. ${ }^{3}$ The Court of Appeal Act 1862, and its successor in 1882, effectively adopted the English procedures which allowed a convicted accused to bring an appeal to the Court of Appeal on a point of law if, and only if, the trial judge was prepared to reserve that point. ${ }^{4}$ There was no remedy if the judge refused to do so. Equally as importantly, the point sought to be reserved had to be raised prior to the imposition of sentence on the defendant. ${ }^{5}$ Any appeal would then be heard by a sitting of all available Supreme Court judges, which would include - until, at the very least, the first decade of the $20^{\text {th }}$ century - the trial judge whose ruling was now challenged. ${ }^{6}$

of his case. Meikle published a partial autobiography in 1904 (John James Meikle The tragic story of Mr JJ Meikle (Wellington, 1904) but no copy is now traceable, and it is not listed in the National Library's Te Puna national catalogue.

2 Peter Spiller, Jeremy Finn and Richard Boast A New Zealand Legal History (2nd ed, Brookers, Wellington, 2002) at 104.

3 ML Friedland "A New Trial After An Appeal from A Conviction" (1968) 84 LQR 48 at 59 and 195. See also the discussion by Chapman J in $R v$ Boakes (1911) 31 NZLR 449 (CA) at 458.

4 Court of Appeal Act 1862, s 69; Court of Appeal Act 1882, s 20. For the English law see WF Craies "Criminal Appeal in England" (1907) 8 J Soc Comp Leg (NS) 93 at 96, and Friedland, above n 3, at 199. Friedland notes that there were no cases of reservation of points to do with the summing up, and few on the admission of evidence.

$5 \quad R v$ Hunter (1878) 4 NZ Jurist 49 (CA); see also $R v$ Taylor (1903) 5 Gaz LR 290.

6 See among many examples $R$ v Drake (1902) 5 Gaz LR 145 (CA) at 148-149; $R$ v Mokomoko (1903) 6 Gaz LR 570 (CA) at 572; and $R v$ Boakes, above n 3, at 458. In $R v$ Woodgate (1877) 2 NZ Jurist (NS) 5 (CA), only two judges sat; the senior, Johnstone $\mathrm{J}$, had been the trial judge. 
This position was changed radically by the Criminal Code Act 1893, which followed the English draft code of 1883 by adding a new ground - that the verdict was unreasonable on the evidence given at the trial. The adoption of the 1883 Code provisions was contrary to the advice of the Commissioners who reported in 1883 to the New Zealand Parliament on the Code. Mr Justice Alexander Johnstone and Walter Scott Reid, the Solicitor General, specifically noted the proposals in the Code for appeals where the verdict was against the weight of evidence, but saw no need for change: ${ }^{7}$

As far as we are aware, the jurisdiction of the New Zealand Court of Appeal, identical with that of the Court for Crown Cases Reserved in England, meets all the ordinary wants of the community in respect of matters of law, and the number of cases which have been submitted to the tribunal in England since its introduction has been notoriously very limited. It may be theoretically proper that some provision should be made in case of a refusal of a [j] udge to reserve a point of law, but in our experience in the colony the tendency has generally been rather to reserve points unnecessarily than to refuse to reserve them .on application. We think that the establishment of a general right to a new trial, especially if grantable on a verdict against the evidence on the application of the prosecutor, might lead to serious delays and not improbable defeats of justice; but, if such a proceeding should be deemed desirable, the limiting provisions of the code which require leave to be given by the Judge who tried the case, and afterward leave to be given by the Court of Appeal in its discretion, would seem to minimize the danger of granting unnecessary or improper new trials.

There was only brief discussion about provision for appeals where new evidence casting doubt on the conviction was later discovered, or where other matters rendered the conviction suspect. The Commissioners considered that adoption of a draft Code provision that allowed a new trial to be ordered where the convicted person applied for the exercise of the royal prerogative - by the grant of a pardon or by the exercise of mercy to commute a sentence - would be adequate. ${ }^{8}$ No-one raised the possibility that this process might be unduly limited because such matters might be raised only after a sentence had been served.

Parliamentarians expressed diverse views about the appeal provisions. Sir Patrick Buckley, the politician who did most to get the 1893 Act passed, ${ }^{9}$ wanted the process for criminal appeals to be broadened, and urged the inclusion of provisions allowing both the prosecution and the accused to

7 Report on the Criminal Code 1883, reproduced in the 1908-1931 Reprint of New Zealand Statutes, vol 2 at 176-181, at [11(1)] [Code Commission Report]. The Commissioners further suggested that appeals on the basis verdicts were unreasonable might be limited to capital crimes only, or conversely might be extended to prosecution appeals as well.

8 Ibid, at $[11(\mathrm{~m})]$.

9 See Jeremy Finn "Codification of the Criminal Law: the Australasian parliamentary experience" in B Godfrey and G Dunstall (eds) Crime and Empire 1840-1940, Criminal Justice in Local and Global Context (Willan Publishing, Cullompton, England, 2005) 224 at 227-228. 
seek to have points of law brought before the Court of Appeal. ${ }^{10}$ Other legislators construed the Bill as creating a Court of Criminal Appeal, an innovation regarded as desirable, ${ }^{11}$ while another, recognising the Bill did not do so regarded that as a shortcoming. ${ }^{12}$ We should not overstate the importance of these references. There is much less discussion of appeals than of other parts of the Bill.

Ultimately the Criminal Code Act 1893 provided for three modes by which a jury verdict of guilty could be challenged. An error of law by the trial judge could be challenged through an appeal by way of case stated. This repeated the earlier appeal on a point of law, but with provision for a convicted accused to seek to have the Court of Appeal state a case or order one to be stated if the trial judge refused. (Under the Crimes Act 1908, parties could also seek leave from the AttorneyGeneral to bring the matter before the Court of Appeal, an option removed in $1920 .{ }^{13}$ )

The second provision was that in s 416, which allowed a convicted accused to seek an order for a new trial on the grounds that the verdict of guilty was against the weight of the evidence at the trial. While facts in evidence at the trial could be reassessed, the appellate court could not consider any factual matters not in evidence at the trial. The first case in which an order was sought under $\mathrm{s}$ 416 for a new trial was $R v$ Styche in $1901,{ }^{14}$ a case in which all the Judges of the Court of Appeal placed great emphasis both on the need for the Court of Appeal not to substitute its own views of the facts for that of the jury and on the advantages the jury enjoyed in observing the demeanour of the witnesses, something which an appellate court could not do.

Lastly, and apparently intended only to apply in exceptional cases, under s 417 the Governor could refer to the Court of Appeal for its opinion whether a new trial should be ordered any case in which a petition had been received seeking the exercise of the Royal prerogative of mercy in relation to the punishment imposed following a conviction. This process was the only one which would allow the Court to consider factual matters not explored at trial, but, as noted earlier, this section was apparently then seen as only applicable if the petition was brought while the accused was still undergoing sentence. ${ }^{15}$

10 (4 September 1893) 79 NZPD 181

11 See CH Mills (Waimea-Picton) (15 August 1893) 81 NZPD 354; Jackson Palmer (Waitemata) (4 September 1893) 81 NZPD 593; and William Pember Reeves (4 September 1893) 81 NZPD 597.

12 AW Hogg (Wairarapa) (4 September 1893) 81 NZPD 595-596.

13 Crimes Act 1908, s 443(1).

$14 R v$ Styche (1901) 20 NZLR 744 (CA).

15 In 1907 the Meikle Commission noted specifically that a pardon could be granted although the sentence had been served in full, a statement which might have been thought unnecessary had there not been some general misperception, "Report of Commission appointed to enquire into the claims of John James Meikle" [1907] AJHR H21 at 48-49 ("Meikle Report"). 
The Act therefore provided no method of challenging a conviction because that matters which had not been before the trial court or not to do with the evidence at the trial showed the verdict was incorrect - the ground now familiar to us as "that there was a miscarriage of justice".

The proximate cause of the creation of a Court of Appeal in England and the conferral on it of jurisdiction to hear appeals on such a broad "miscarriage of justice" ground was the case of Adolph Beck, who was wrongly convicted - twice - on the basis of mistaken but honest eyewitness evidence as to the identity of the offender. The first such conviction followed some decidedly suspect tactics by the prosecution and wrong and unfavourable rulings by the trial judge which prevented potentially conclusive evidence being adduced to challenge the prosecution's case. ${ }^{16}$ The judge also refused to state a case for appeal. ${ }^{17}$ Several petitions following the conviction were mishandled by the Home Office, which did nothing even after the key prosecution evidence was completely discredited.

When at last the "miscarriage of justice" ground was added in New Zealand in 1945, the Attorney-General, Rex Mason, indicated that the need for such a ground of appeal had been shown by the Beck case, ${ }^{18}$ although he did refer to the Court of Appeal's views in $R v$ Styche as to the limits of its jurisdiction and to Justice Chapman's 1911 criticisms of their limited scope.

\section{CHEMIS'S CASE AND THE DEFECTS IN THE CRIMINAL APPEAL PROVISIONS}

The limited nature of the grounds of appeal was demonstrated most spectacularly in the case of Louis Chemis who was convicted of murder in 1889 on the basis of strong but not compelling circumstantial evidence. ${ }^{19}$ The defence was unable to present an alibi provided by his wife because at that time neither an accused nor his or her spouse could give evidence. ${ }^{20}$ Further concerns as to

16 Many of the relevant documents are reproduced in The Strange Story of Adolph Beck (London, HMSO, 1999). The prosecution theory was that Beck was in fact a fraudster known as John Smith (see prosecution brief (at 36) but at Beck's trial the Common Sergeant, Sir Forrest Fulton, refused to order the prosecution to include counts in the indictment relating to offences committed by Smith in 1877, and refused to admit defence evidence that Beck had been in South America throughout 1877 and therefore could not have been Smith. Sir Forrest Fulton's hostile rulings may have been motivated by a strong belief that the evidence as to Beck being in South America was to be regarded with "great suspicion" (see his report to the Homes Secretary, reproduced at 94).

17 Craies "Criminal Appeal in England", above n 4, at 96.

18 (1 August 1945) 268 NZPD 780.

19 There is apparently no full account of that case, but a short account is available: CAL Treadwell "Famous New Zealand Trials - The Trial of Louis Chemis" (1 May 1934) 9(2) The New Zealand Railways Magazine 24 , available at <www.nzetc.org>.

20 One major consequence of Chemis' case was that it spurred the then Premier, Harry Atkinson to introduce the Criminal Evidence Bill 1889 which allowed the accused and the accused's spouse to give evidence, nine years before the British Parliament legislated on similar lines. The right to give evidence had been suggested 
the guilty verdict were raised when it became known that senior counsel for the accused, $\mathrm{Mr} \mathrm{C} \mathrm{E}$ Bunny, ${ }^{21}$ had been suffering with typhoid fever during the trial, and died of that disease only a few days afterwards. For reasons not known, but possibly to do with the doubts surrounding the verdict, Chemis's sentence was commuted to life imprisonment. There were no issues of law which would allow an appeal, so Chemis was left without legal recourse.

The Criminal Code Act 1893 contained express provisions limiting its application to cases decided after it came into force. Chemis and Meikle and others who claimed to have been wrongly convicted prior to 1893 were therefore barred from appealing. However in both 1894 and 1895 there was considerable agitation to make retrospective provision for Chemis to appeal under the Act. ${ }^{22}$ There were bitter clashes in Parliament about the propriety of any such retrospective legislation and whether any such legislation should apply only to Chemis or should allow appeals in other cases Meikle being mentioned as one possibility. There was, however, no real discussion of the basis on which any such appeal might be brought. The first attempt in 1894 was tacked on to an amendment to the age of consent for sexual offences, and proposed allowing all persons convicted since 1 January 1889 to apply to the Court of Appeal for a new trial, presumably to make it somewhat less obvious that the measure was intended to benefit Chemis. However the Bill was amended to confer a right on Chemis - alone - to seek an order from the Governor for a new trial. ${ }^{23}$ The amended Bill passed the House of Representatives but was rejected by the Legislative Council, who persisted in their stance despite efforts to broker an agreement. ${ }^{24}$ For the Legislative Council the principle was clear, as was its application to the facts: ${ }^{25}$

It is undesirable that Parliament should constitute itself a Court of review of the decision and verdict of the Supreme Court, and that in the case of the convict Chemis he was found guilty by a jury of his countrymen after an exhaustive trial and duly sentenced to death.

In 1895, after further prolonged argument, Parliament passed the Criminal Code Amendment Act 1895 which specifically permitted Louis Chemis - but no one else - to seek the leave of the

in the Stephen Code but the New Zealand Code Commissioners had deliberately refrained from making any recommendation on the issue: Code Commission Report, above n 7, at [11(j)].

21 Charles Edward Bunny was articled in Dunedin to John Bathgate on 21 September 1871; he was admitted as a barrister (only) on 27 February 1877 in Wellington. He is described in RB Cooke (ed) Portrait of a Profession (AH and AW Reed, Wellington, 1969) at 400 as practising on his own account in Wellington from 1877 "mainly as a barrister".

22 Information as to the petitions brought seeking some kind of appeal appears in a newspaper report at the time of Chemis's death: Evening Post (Wellington, 24 October 1898) at 5.

23 (13 September 1894) 85 NZPD 658-659.

24 See (15 October 1894) 86 NZPD 755-758; and (20 October 1894) 86 NZPD 981-986.

25 See (15 October 1894) 86 NZPD 758. 
Court of Appeal to appeal against the guilty verdict and to seek an order for a new trial. The measure was well-supported in the House of Representatives but passed the Legislative Council by a single vote. ${ }^{26}$ It is clear that Chemis's partisans in Parliament intended that the legislation to allow Chemis to adduce the alibi evidence to impugn the conviction. ${ }^{27}$

If this was the aim of the statute, it was not fulfilled. As could have been foreseen on a simple reading of the statute, the only grounds Chemis could advance were those in the 1893 Act. When an application for a new trial was made, ${ }^{28}$ the Court made it clear to counsel for Chemis that any appeal would have to show that the verdict was unreasonable on the evidence before the court at trial. ${ }^{29}$ The special Act did not allow the appellant to raise new evidence not before the court at the trial, whether it was the alibi evidence of the accused and his wife or evidence as to other possible culprits. Mr Jellicoe, counsel for Chemis, is reported as having said that on that basis the appeal could not be supported. The application for leave was dismissed. Two years later Chemis was released from prison as one of a number of prisoners granted clemency on the occasion of Queen Victoria's Diamond Jubilee, but he committed suicide shortly thereafter. ${ }^{30}$

The dismissal of the application for a new trial prompted one of Chemis's strongest parliamentary supporters to call, unsuccessfully, for further legislation to allow the case to be reopened before the Court of Appeal. ${ }^{31}$ During that debate Meikle was instanced as another person allegedly wrongly convicted and imprisoned. ${ }^{32}$ It is evident that several members were familiar with Meikle's case; which had by then been before the House Petitions Committee.

\section{JOHN JAMES MEIKLE AND HIS TRIAL FOR SHEEP- STEALING}

Meikle was a farmer who owned, in his own name or that of his children, 800 acres of land near Tuturau in Eastern Southland. A larger farming operation - the New Zealand Mortgage and Investment Association (NZMIA) - owned one adjoining block of land and leased another. The

26 See (5 July 1895) 87 NZPD 403-406; (13 August 1895) 89 NZPD 9-10; and (14 August 1895) 89 NZPD 6874.

27 See for example (13 August 1895) 89 NZPD 10.

28 Chemis v Queen (1895) 14 NZLR 393 (CA).

29 Ibid, at 394. The point is adverted to, in very cryptic terms, by Stephen White "The making of the New Zealand Criminal Code Act 1893: a Sketch" (1986) 16 VUWLR 353 at 370; recourse to the sources cited by White make it clear he meant that the 1894 Bill did not contain restrictions on the grounds the Governor could consider.

30 These details of Chemis' life are taken from Treadwell "Famous New Zealand Trials - The Trial of Louis Chemis", above n 19.

31 (24 June 1896) 92 NZPD 295.

32 (24 June 1896) 92 NZPD 300 
Association had been founded by Dunedin entrepreneur and lawyer John Bathgate, while serving as Resident Magistrate and District Court Judge in Dunedin. ${ }^{33}$ It suffered significant stock losses, which it attribute to theft. Meikle was clearly the prime suspect. There was an incident where Alexander M Aulay, an NZMIA employee asked Meikle to muster his sheep (so that any NZMIA stock on his land through normal escape of sheep from one property to another could be recovered), Meikle took umbrage and assaulted M'Aulay. ${ }^{34}$ Meikle was prosecuted for assault, and sentenced to a month's imprisonment. He and M'Aulay then brought reciprocal accusations of perjury over the case. Meikle failed to convince the local magistrate to commit M'Aulay for trial, while Meikle was twice tried but in each case the jury failed to agree on a verdict, and then a nolle prosequi was filed. $^{35}$

In 1887, NZMIA brought a charge of theft against Meikle. It could establish that more than 20 of its sheep were on Meikle's land, not far from the common boundary but in an area where the fences were sufficiently good that it was unlikely they had all got on to Meikle's land of their own accord. That of course would not prove theft. The critical evidence for the prosecution was that of William Lambert who testified that he had found two sheepskins bearing the company's mark in a shed on Meikle's property. Lambert, it emerged during the prosecution, had been employed by NZMIA as a private detective to get evidence against Meikle and had worked for some months undercover on its farm. Lambert later admitted he had been offered the very substantial sum of $£ 50$ to procure a conviction of the stock thief.

Meikle was tried and convicted of sheep stealing in the Supreme Court at Invercargill in December 1887. The trial was presided over by a temporary judge of the Supreme Court, Charles Dudley Robert Ward. Ward was then the District Court Judge for Wellington, ${ }^{36}$ and apparently a man of combative nature, ${ }^{37}$ Certainly his conduct at different times in Meikle's case suggests a serious lack of judicial detachment.

Meikle had apparently arranged for legal representation at his trial, but counsel withdrew during the first day of the trial (perhaps because Meikle had referred to them very disparagingly during the

33 Geoffrey F Vine "Bathgate, John 1809-1886" (2007) DNZB, above n 1.

34 "Meikle Report", above n 15, at 48-49. The "Meikle Report" names the other party as McCauley, but another report of the case "Resident Magistrate's Court" Mataura Ensign (Gore, 7 October 1884) names him as M'Aulay.

35 This account of the M'Aulay affair is based on the (hostile) speech of Mr Remington MHR (22 October 1907) 142 NZPD 27.

36 This was one of four such temporary appointments; he also refused a permanent appointment in 1896: The Cyclopedia of New Zealand: Otago \& Southland Provincial Districts (Christchurch Cyclopedia Company Ltd, Christchurch, 1905) at 525. His most notable case as a temporary judge was the application to strike Henry Smythies off the Roll of Barristers and Solicitors; Re Henry Smythies (1869) Mac 702.

37 See RB Cooke (ed) Portrait of a Profession, above n 21, at 144. 
luncheon adjournment). ${ }^{38}$ Meikle then had to present his own defence. As noted earlier, at that time neither he nor his wife were able to give evidence. Meikle was convicted.

Following the jury's verdict, Ward sentenced Meikle to seven years imprisonment, the maximum for the offence, on the basis that Meikle was "the head and front of this offending" in the district and ran a gang of stock thieves, relying for immunity from the consequences simply on the "hard swearing" he was able to procure. Ward stated that Meikle had trained his son to perjury and his servants to plunder, and that every honest farmer within 10 miles of Meikle's neighbourhood would sleep sounder because of his conviction. ${ }^{39}$ There does not appear to be any foundation for this view in the evidence produced during the trial; we may suspect Ward was reliant on information from others hostile to Meikle.

Meikle did not serve the full seven year term, being released early because he had defended a prison warder who had been attacked by other inmates. ${ }^{40}$ During his imprisonment the family endured serious hardship and poverty, and Meikle's eldest son died - according to one later Parliamentary speech because of the family's inability to feed him properly during a period of illness.

\section{MEIKLE'S FIRST ATTEMPTS TO IMPUGN THE CONVICTION}

Almost immediately on Meikle's release he began agitating for redress. ${ }^{41}$ The first step, in 1894, was to attempt to prosecute Lambert for perjury. Lambert was committed for trial by the local Stipendiary Magistrate but the Grand Jury threw out the bill. In March 1895, Meikle brought fresh charges, alleging not only perjury at the 1887 trial but also in the 1894 committal proceedings. Both charges were dismissed by a magistrate. Not discouraged, Meikle brought another charge of perjury at the 1887 trial. This time the matter went to trial, before Williams $\mathrm{J}$ and a jury. ${ }^{42}$ Many witnesses were called and gave essentially the same evidence as at Meikle's trial. In addition there was the testimony of Meikle, his wife and Lambert. The jury convicted Lambert of perjury.

The perjury trial was only one element of Meikle's activity to seek to clear his name. He apparently held a number of public meetings to ventilate his grievances. A newspaper described one

38 See (3 July 1908) 143 NZPD 144. Meikle's character makes the story plausible.

39 See speech by Fisher (26 September 1905) 135 NZPD 187. Fisher was an intemperate advocate for Meikle's cause, but here he was apparently repeating verbatim a report of the sentencing. No issue as to accuracy was raised by Meikle's detractors.

40 (5 July 1895) 87 NZPD 405.

41 Counsel before the Commission, indicated he had addressed a public meeting in Wyndham on the point a month after his release: "Meikle Report", above n 15, at 17.

42 This account is based on counsel's opening statement to the Commission, ibid, at 17-18. 
meeting in Invercargill in November 1895 as attracting an audience of over 200 - uncharitably ascribed to there being no entry fee - who were regaled with an extraordinary diatribe against both the government and Judge Ward. To add a touch of theatre, Meikle had dressed himself in prison garb and was accompanied on stage by a young son dressed as prison warder. ${ }^{43}$

\section{THE PETITIONS PROCESS - ROUND 1}

In 1895 Meikle petitioned Parliament for redress for his allegedly wrongful conviction and imprisonment, seeking payment of the legal expenses incurred in prosecuting Lambert, compensation for losses suffered during the years that Meikle had been in prison and the removal of his name from the record of persons convicted. While there was no record of the proceedings before the Petitions Committee, their nature is evident from the subsequent debates. The Committee made what was apparently a majority recommendation in Meikle's favour: ${ }^{44}$

The Committee recommends the Government to make provision on the supplementary estimates for the payment to petitioner of a sum of money by way of compensation for the loss he has sustained in connection with his business, the legal costs incurred in defending the charge preferred against him, and in securing the conviction of Lambert for perjury, and also by way of compensation for the imprisonment he has suffered.

It also recommended that favourable consideration be given to Meikle's request that his name be in some way expunged from the records of those criminally convicted. ${ }^{45}$

No precise figure is then given for the compensation Meikle was seeking. In a further petition, in 1897 , Meikle apparently put a claim totalling $£ 2823$, on the basis of: ${ }^{46}$

Costs of defending case in 1887.

$£ 208$;

prosecuting Lambert for perjury

$£ 955$,

loss of 500 sheep (stolen or strayed),

$£ 250$;

loss through forced sale of his stock and farm-implements,

$£ 230$;

loss on grain-crops through forced neglect,

$£ 165$;

interest accrued on mortgage during his imprisonment, which he

was prevented from earning,

$£ 1,265$;

eight years' loss of profits of his farm, at $£ 200$ a year;

$£ 1,600$;

other unnecessary expenses in connection with his farm owing to his

enforced absence

43 The Star (Christchurch, 30 November 1895) at 7.

44 (29 October 1895) 91 NZPD 858.

45 (10 September 1896) 95 NZPD 489.

46 (2 December 1897) 100 NZPD 274. 
The Government was not inclined to act on this recommendation. Richard Seddon, the Premier, replied to a question from Robert McNab, the MHR for Mataura (and thus for the area in which Meikle's farm lay), as to whether the Government intended to act on the report of the Petitions Committee, by stating that the report would be considered but "this was not the only case, and a dangerous precedent might be established". ${ }^{4}$ In 1896, McNab again asked whether the recommendation of the Petitions committee would be implemented. ${ }^{48} \mathrm{He}$ drew the non-committal response that the report of the Committee would be considered by Cabinet in the usual way before the close of the session.

Meikle presented a fresh petition in 1897. It is evident that Meikle relied largely then - as in 1895 - on the fact that Lambert was the chief witness against him and had now been discredited and convicted. The Petitions Committee sought reports from both Judge Ward and Williams J in relation to the trials of Meikle and Lambert respectively. Judge Ward would not concede that Meikle had been exonerated or wrongly treated. In a passage frequently quoted in later years, Ward argued that Lambert's conviction showed only that his evidence should be removed from consideration, rather than demonstrating Meikle's innocence: ${ }^{49}$

Had there been no evidence beyond this I should certainly not have directed the jury to acquit; but the case for the Crown would have been greatly weakened, and probably the able counsel engaged by Meikle would then have secured his acquittal, had it not been for the exposure of the gross perjury committed on Meikle's behalf by the witness Templeton which might have turned the scale the other way ...

The implication that although Meikle had been acquitted, he was actually guilty of the crime, is scarcely veiled. Ward also implied that Meikle had suborned perjury to avoid conviction. Meikle's partisans were quick to point out that the alleged "perjury" consisted of a witness, John Templeton, giving an erroneous date for a conversation in which he had been involved, and then of his own volition correcting his testimony on the following day after having had an opportunity to check his records. ${ }^{50}$ For Ward, a judge, to describe that as perjury is remarkable; to attribute it to Meikle as suborned perjury was grossly unjudicial.

Once again the Petitions Committee recommended favourably, though not to the point of recommending payment of the amount of compensation sought. Seddon himself thought there was no basis for any compensation, and indeed indicated that the Government considered that Meikle

47 (29 October 1895) 91 NZPD 858.

48 (10 September 1896) 95 NZPD 489.

49 As cited in (16 November 1897) 100 NZPD 5.

50 See Mackenzie (2 December 1897) 100 NZPD 271. 
had been properly convicted. ${ }^{51}$ Nevertheless it appears that the Cabinet was willing to reimburse Meikle for the costs of the perjury prosecution, but only on the much more limited scale of costs which would have been paid to a Crown Solicitor, and without reimbursing him for the very substantial costs of witness expenses incurred during the proceedings, including the unsuccessful first two prosecutions.

The Government also eventually was prepared to provide some general compensation and made an offer of $£ 500$ in full settlement of any claims by Meikle relating to the wrongful conviction and imprisonment. That figure, very much below the amount Meikle was seeking, was allegedly selected because McNab had privately informed a member of the Cabinet that Meikle would accept that smaller sum. ${ }^{52}$ There is no evidence that Meikle was ever consulted on this point.

It appears that Meikle objected to the small size of the sum but, after his partisans in Parliament had failed to persuade the Government to increase its offer, he finally accepted payment. After orally stating that the sum was accepted under protest as being inadequate, he nevertheless signed a receipt which stated that the money was accepted in full settlement of his claim, without any addition of words indicating that it was not accepted in that sense. This receipt was frequently referred to in later Parliamentary arguments, with some saying the receipt should be taken as genuinely evidencing settlement of the claim, others that it had been effectively extorted by duress of circumstances and should not be not a bar to a claim of further compensation. It seems likely that Meikle's decision to take what he could get was influenced by pressure from his creditors. It seems probable he had borrowed a substantial part of the money spent on his legal and political campaigns. In 1898 Meikle was imprisoned for debt on an action brought by a Mr Levy; Meikle was to later attempt - unsuccessfully - to sue Levy for false imprisonment, ${ }^{53}$ on the argument that Levy had presented his claim to the court in breach of an agreement with Meikle not to do so.

There the matter rested for some years, as far as Parliament was concerned. Meikle was evidently left with a strong sense of grievance over the outcome of the petition process and continued to agitate for further compensation and for his name to be deleted from the record of those convicted. In 1901, he ran as an independent candidate in a parliamentary by-election in the Dunedin seat of Caversham - finishing a resounding last in the poll with a mere 27 votes. ${ }^{54}$ More pertinently he travelled around New Zealand, addressing public meetings on the issue. In these speeches, he not infrequently alleged a variety of forms of misfeasance on the part of Judge Ward, the Cabinet and others, amounting to a conspiracy to deny him his rights. ${ }^{55} \mathrm{He}$ also frequently

51 See (2 December 1897) 100 NZPD 275.

52 See (16 November 1897) 100 NZPD 1-2.

53 See The Southland Times (Invercargill, 1 April 1898) at 3; and The Star (Christchurch, 1 October 1898) at 6.

54 See Bush Advocate (Dannevirke, 20 December 1901) at 3.

55 See, for example, the report of a speech in Bruce Herald (Milton, 30 August 1901) at 5. 
attacked the character of Joseph Ward, then the Colonial Treasurer ${ }^{56}$ - quite possibly on the basis of the involvement of Ward's company in taking possession of the farm, under a lien over the growing crops, after Meikle was convicted.

In the course of this campaign he brought a defamation action against the New Zealand Times newspaper, based on the publication in 1903 - presumably to discredit Meikle's continuing campaign - of a letter written by Judge Ward in 1888, in relation to another case of alleged sheepstealing. Meikle had been called - from prison- as a witness for the defence. Ward's letter apparently written to the Ministry of Justice - alleged in blunt terms that Meikle was himself the ringleader of a sheep-stealing gang, that he had given perjured evidence to shield a confederate and had falsely tried to implicate an innocent person as the real offender. ${ }^{57}$ Meikle promptly sued for defamation. There were procedural skirmishes in which Meikle was successful in getting much of the statement of defence struck out, ${ }^{58}$ and in opposing an order for a change of venue. ${ }^{59}$ Although the trial jury returned a verdict in Meikle's favour, it awarded only a contemptuous farthing in damages.

Meikle also brought a second libel action, apparently based on the same letter by Ward, in which he pursued the Premier's private secretary, Thomas Hamer, and the Government Printer, John Mackay, for their role in transmitting the letter before publication. In that case, Meikle accepted a non-suit during the trial, but was required to pay costs on the highest scale. ${ }^{60}$

\section{THE PETITIONS PROCESS ROUND 2}

In 1903, Meikle was back before the Petitions Committee of the House of Representatives seeking further redress. The debates in the House indicate he was then more concerned to have his name removed from the list of those convicted than with seeking further monetary compensation. ${ }^{61}$ The Petitions Committee were sympathetic, with the Committee Chairman informing the House that something should be done but he could not identify an appropriate mechanism. Had Meikle been

56 See the critical comment on Meikle in NZ Truth (Wellington, 2 November 1912) at 5.

57 The nature of the allegations is made fairly clear in Meikle v New Zealand Times Company Ltd (No 2) (1904) 23 NZLR 893 (SC) at 894.

58 Meikle v New Zealand Times Company Ltd (1904) 23 NZLR 891 (SC).

59 Meikle v New Zealand Times Company Ltd (No 2), above n 57.

60 Wanganui Herald (Wanganui, 16 August 1904) at 7.

61 In a debate in September 1903, note was taken that the Estimates did not include provision for any payment to Meikle, see (8 September 1903) 125 NZPD 373, but nothing in the record indicates Meikle was actively pursuing a financial claim. 
still serving a sentence of imprisonment, the committee could and would have recommended that a pardon be granted. ${ }^{62}$

It was in that debate, in September 1903, that the first mention is made of a possible extraordinary remedy by way of a statute declaring Meikle innocent. ${ }^{63}$ James McGowan, the Minister of Justice, suggested that a bill could be passed striking Meikle's name of the records but that was all could be done. Mr Hanan, MHR for Invercargill, agreed there should be a remedy and a special act of Parliament would be necessary. He recommended that the matter be sent back to the committee to discuss whether a bill of that kind should be passed. Richard Seddon, the Premier, joined the debate, agreeing that that a statute would be necessary and saying he was willing to take the matter up with the other members of the government even though the committee had come back without a formal recommendation. ${ }^{64}$

After further questions in the House, ${ }^{65}$ Seddon made a formal statement of the Government's position in November 1903.66 Seddon's starting point was that of many MPs opposed to any remedy in earlier years - that Lambert's conviction for perjury was not the same as conclusive proof of Meikle's innocence. He therefore considered it had not been shown that removal of Meikle's name from the roll of persons convicted was proper - even if such erasure had been possible. The Government was, however, prepared to ensure that printed slips recording the fact of Lambert's conviction for perjury would be placed in all appropriate official records of Meikle's 1887 trial and conviction. Further financial compensation would not be offered.

In 1905, yet another petition was presented on Meikle's behalf. The Petitions Committee recommended that Meikle's name be removed from the criminal records by tags or such other method as might be found practical, but did not recommend the payment of compensation. ${ }^{67}$ McGowan strongly opposed any action on either head - on the bases that removal of the records was impractical, and that the 1897 receipt and discharge precluded any further claim. ${ }^{68}$

There was, however, for some reason a change of heart within the cabinet, and only a few weeks later Seddon told the House of Representatives that the Government had decided to set up a Commission to investigate Meikle's case fully, and it would look at the circumstances in which the

62 (1 September 1903) 125 NZPD 172.

63 (1 September 1903) 125 NZPD 173.

64 (1 September 1903) 125 NZPD 175.

65 (21 October 1903) 126 NZPD 654-655.

66 (21 November 1903) 127 NZPD 993.

67 (26 September 1905) 135 NZPD 181.

68 (26 September 1905)135 NZPD 182. 
1897 payment was received, as well as matters relating to the prosecution of Lambert. ${ }^{69}$ Why there was this change of stance is not clear. It is perhaps significant that only a few days later an opposition MP could ascribe the enactment of provisions relating to criminal libel to the Government desire to bring to an end public attacks on Ministers by Meikle and one Braund. ${ }^{70}$ Between the threat of prosecution and the lure of possible compensation, Meikle would have been neutralised.

\section{THE COMMISSION AND ITS AFTERMATH}

The government appointed as Commissioners two Supreme Court judges - Worley Basset Edwards and Theophilous Cooper. The judges examined the evidence at the trials and heard those witnesses who were still available. It would appear that Edwards J, at least, entertained considerable doubt as to Meikle's innocence. Certainly the Commissioners considered Meikle's moral character had been irreparably damaged by the combination of a liaison with a young woman and his denial of that liaison while suggesting she had had an affair with his nephew. ${ }^{71}$ In essence, they could have understood him lying to protect her reputation - but not to protect his own or traduce hers. Meikle's denials could not have been convincing. The relationship - with a Miss Mills - had apparently started not long after his release from prison, and they had a child in $1901 .^{72}$

The final report of the commission, which was issued in 1907, concluded that although the conviction of Lambert for perjury did not prove Meikle's innocence, the rest of the Crown case could not have supported a conviction.

This then led to a considerable debate as to what further steps could be taken. In 1907 the Government proposed a unique bill - the Meikle Acquittal Bill 1907 - which declared that his conviction was expunged. The second reading in the House of Representatives of that Bill prompted a substantial debate. The Prime Minister, Joseph Ward, was at pains to argue that the Bill was designed to carry out the recommendations of the Commission. ${ }^{73} \mathrm{He}$ also argued that a bill specifically dealing with Meikle was preferable to a more general measure because there was the risk of a general provision turning into a process of reconsidering the decisions of the Supreme Court. $^{74}$ (A motion at committee stage to amend it to a more general statute was ruled out of

69 (13 October 1905)135 NZPD 727-728

70 Mr Taylor (Christchurch Central) (19 October 1905) 135 NZPD 868-869.

71 "Meikle Report", above n 15, at iii.

72 Meikle and his wife became estranged during his imprisonment. After she died in 1920 Meikle married Mills. See J Findlay McArthur "Meikle, John James", above n 1.

73 (22 October 1907).142 NZPD 1.

74 (22 October 1907)142 NZPD 31. He reiterated this view later, see (4 November 1907) 142 NZPD 445. 
order. $)^{75}$ The Committee stages of the Bill, and a later debate on a Ministerial statement on the Bill by Ward provoked very substantial argument. ${ }^{76}$ Some parliamentarians saw merit in Meikle's claim, others considered that he was guilty of the offence and others thought him possibly innocent but morally undeserving of a remedy. Others simply thought the Bill an undesirable precedent. The Bill passed the second reading 42-12.

Two elements of interest in the debate were the reported views of Sir Robert Stout, the Chief Justice, and his colleagues and some discussion of the proper basis for provision for criminal appeals. The judges' views appear in two speeches by Ward. He had indicated to the House in early November ${ }^{77}$ that it was now thought necessary to consult the Judges as to the form of any general measure (as the Commission had recommended). Ward insisted that restricting the legislation to Meikle's case conformed to principle: ${ }^{78}$

With regard to what is being asked for - practically to appoint a Board of Appeal to criticise and review the decisions of the Supreme Court Judges of this country - we are not prepared, with the responsibility on our shoulders to the people of New Zealand, to do anything, even after consideration by all the recommendation of a royal commission, that would in any way be capable of being regarded by people inside and outside of this Dominion as a weakening of the power or the decisions of the judges of the Supreme Court of this country.

Two days later Ward made a statement to the House indicating he had consulted Sir Robert Stout, who had informed him that judges had considered "the proposed amendment of the law recommended by the Meikle commission" and: ${ }^{79}$

...they are unanimously of the opinion that, seeing that the question of appeals in criminal cases is being legislated upon in Great Britain, it would be wise for the government to defer any action until the full text of the English legislation has been received here and considered. They would therefore recommend that no steps be taken to pass any legislation on the subject.

The reference is to a Bill for the establishment of a Court of Criminal Appeal for England and Wales, a Bill first introduced in 1906 and passed in 1907.

Further discussion took place the following day, with Ward telling the House that he had asked the judges, through Stout, to prepare legislation which would carry out the Commission's

75 (24 October 1907) 142 NZPD 187.

76 See (24 October 1907) 142 NZPD 187; (4 November 1907) 142 NZPD 445-447; and (4 November 1907) 142 NZPD 579-586.

77 (4 November 1907) 142 NZPD 449.

78 Ibid.

79 (6 November 1907) 142 NZPD 511, citing Stout to Ward 2 August 1907. 
recommendations and allow Parliament to pass legislation early in the next session. He had also asked Stout to seek the opinion of the judges as to "such measure, if any, of compensation as, based upon the broadest equitable lines, will be substantial justice to [Meikle], or, in the alternative, what sum of money, if any, under all the circumstances, should be paid to [Meikle]." 80 Stout had replied that no meeting of the Judges would take place until March 1908, and the issues would be raised then.

Stout's suggestion that nothing be done until the British parliament had dealt with the proposal for a Court of Criminal Appeal was, not surprisingly, seized on by some of Meikle's opponents, who could argue that a general measure was fairer than a provision for Meikle alone - and that nothing should be done for the moment. ${ }^{81}$ Others took a different line. F A Baume, a prominent Auckland lawyer and MHR for Auckland East, insisted that a general statute should not attempt to create a separate Court of Criminal Appeal: ${ }^{82}$

What the government had attempted to do in this particular case, and all that could be expected of any government, is to try and remedy that which is acknowledged to have been a miscarriage of justice in a particular case - a miscarriage of justice the like of which is bound from time to time to occur in any country, however perfect its judicial procedure may be. Such miscarriages of justice it is absolutely impossible to provide for in general legislation...

The Bill was then dropped for the session.

In 1908 the Government again brought forward a Bill restricted to Meikle. Ward explained that Stout had informed him that the judges had not had opportunity to discuss the general question fully, but Stout had advanced his personal views. As regards criminal appeals generally, Stout considered: ${ }^{83}$

...[a]ny general measure designed to set right convictions which are wrong, and so to avoid the scandal of innocent persons suffering, would be in the direction of extending to some extent the existing right of appeal in criminal cases. How this is to be carried out would require long and careful consideration. It would be as well to ascertain how the Court of Criminal Appeal just established in England works before bringing forward any comprehensive measure.

Stout referred to the possible appeals under ss 416 and 417 of the Criminal Code, noting these had not been in force when Meikle was tried. On the issues relating to Meikle's case, Stout was clear

$80 \quad$ (7 November 1907) 142 NZPD 579.

81 See for example Mr Hornsby (MHR for Wairarapa) (7 November 1907) 142 NZPD 581.

82 (7 November 1907) 142 NZPD 583.

83 (3 July 1908) 143 NZPD 139. 
and forceful. The judges should have no role in assessing any compensation. That was a matter for Parliament. Stout and the judges, however, saw no case for payment: ${ }^{84}$

[W]e have not overlooked the fact that this is not a simple case where it has been clearly proved that an innocent man has been unjustly punished and has received no compensation. First, an amount of compensation has been paid and accepted. Second, the commission that investigated the case only found that the evidence was insufficient to warrant the jury in convicting. Their finding would have been one of "[n]ot proven" in a Scottish court. Third, the commission stated that a part of the evidence given by Mr Meikle before them was admittedly false.

Ward quite properly took issue with some of Stout's statements, correctly noting the Commission had indeed found that Meikle should have been found not guilty. He then made the, perhaps surprising, statement that the government had decided a compensation figure of $£ 5000$ was appropriate. ${ }^{85}$ On the general issue of criminal appeals he was less forthcoming: $: 66$

In the matter of an appeal court for criminal cases, we require to approach the matter very cautiously

before we establish this country what has been done in the Mother Country.

The leader of the Opposition, W F Massey, then probably ensured the passage of the Meikle Acquittal Bill by supporting it, and despite some continued resistance the Bill passed its second reading comfortably.

Some diehard resistance was offered at the third reading, but the debate there is most notable for Baume's championing of the recommendation by the Commissioners that the Attorney-General should have the power to bring a case before the Court of Appeal to have the conviction quashed. ${ }^{87}$ While the Crimes Act 1908 was enacted without debate as part of the general consolidation of the statute law in that year, it nevertheless included a new provision allowing the Attorney-General to give leave to a convicted person to bring a case to the Court of Appeal, perhaps in response to the Commissioner's recommendations.

This final House debate was dominated more by allegations that Meikle had the backing of a shadowy syndicate out to loot the public purse by sharing in an unjustifiably large payment of compensation than by argument as to the merits of the Bill. The Bill passed 37-17, and then went through the Legislative Council without incident.

This was not the end of the Meikle affair. In 1909, a further attempt to persuade Parliament to award compensation was made, with the Government moving the inclusion in the estimates of a

84 (3 July 1908) 143 NZPD 139.

85 (3 July 1908) 143 NZPD 141.

86 (3 July 1908) 143 NZPD 140.

87 (8 July 1908) 143 NZPD 243. 
sum of $£ 5,000$ by way of compensation. This was vigorously opposed by a number of parliamentarians, some of whom were still committed to the theory that Meikle was truly guilty of the offence for which he had been convicted; others relied on the 1897 payment and quittance. Others again waved the bogey of an alleged syndicate backing his claim. Meikle's public backers, the Meikle defence committee which included several members of Parliament, frequently but unavailingly denied those rumours. The opponents of compensation successfully moved that the sum of $£ 5,000$ be reduced by $£ 4,999$ so as to leave a token $£ 1$ in compensation. Not surprisingly at this point, the matter was dropped.

However this was not the final chapter. In 1910, Meikle's partisans tried once more to secure compensation of $£ 5,000$, and in a rather bizarre debate, the House reached a consensus that it would not award the full $£ 5,000$ but rather half that sum. ${ }^{88}$ Meikle accepted this sum, but without regarding it as a satisfactory outcome. Indeed, in 1911 it was reported that he intended to travel to Britain at the time of the colonial conference so that he could raise with the British public the failure of the New Zealand legal system and government to deliver justice to him. ${ }^{89}$

Meikle's later years were dominated by a lingering sense of injustice and sporadic attempts to persuade the government to give further compensation. Whether from lack of means or because of a possibly bitter relationship with his wife, Meikle - then described as "of Epsom, Auckland" was in 1913 to be pursued by his wife for failure to pay maintenance for his youngest child - and ordered to be committed to prison unless the $£ 28$ due was paid. ${ }^{90} \mathrm{He}$ was in later years to seek, unsuccessfully, a special pension of $£ 4$ per week form the Government. ${ }^{91}$

\section{THE DISAPPEARANCE OF CRIMINAL APPEALS AS A SUBJECT OF DEBATE 1910-1945}

It is now necessary to return to the point at which the Meikle saga intersected with the more general question of possible changes to the law relating to criminal appeals and of the possible institution of a Court of Criminal Appeal - most notably in the Parliamentary debates in 1907 and 1908. Given the apparent broad support for some change to the system and the example of the English court, some concrete proposal for reform might reasonably be expected to emerge. Yet none did. In part this may be because, as recounted earlier, the judges were considerably less than supportive of proposals for a new court.

88 This debate and the outcome appear to have escaped the notice of the author of the DNZB entry for Meikle.

89 Grey River Argus (Greymouth, 29 May 1911) at 8. McArthur, in his DNZB piece, indicates Meikle visited Britain and the USA, but dates the trip to 1912.

90 Evening Post (Wellington, 1 August 1913) at 8.

91 Evening Post (Wellington, 9 December 1929) at 13. 
What is striking is that an issue which was clearly widely debated suddenly drops almost completely off the public agenda. From the beginning of 1910 until the enactment of a substantial change to the legislation in 1945 to allow the Court of Appeal to consider miscarriages of justice however occurring - in the Crimes Amendment Act 1945 - there was only one Parliamentary reference to a possible Court of Criminal Appeal or appeals against conviction. Massey, the Prime Minister was asked in October 1915 whether the government would consider introducing a Bill on English lines for a Court of Criminal Appeal. He replied that it would not be possible to deal with the matter during that session but it would be considered during the recess. There was however a significant change to the law in 1920 which allowed convicted defendants to appeal against sentence only. This Bill passed on its third attempt, though the earlier failures seem to have been more from timing than resistance. The amending Bill was generally welcomed and quickly passed. ${ }^{92}$

Nor does there appear to have been any particular enthusiasm among the judiciary or the profession for reform of the law as to criminal appeals. While Chapman J in 1911 judicially indicated that the provisions in the Crimes Act were too limited, ${ }^{93}$ the other judges were clearly very reluctant to involve themselves in any matter which required a review of factual matters occurring outside the trial, a function they noted could be carried out by the Governor-General and Executive Council where an application was made under the Crimes Act. This is so even though the facts of $R$ $v$ Boakes - as most of the Judges commented-provide an almost perfect example of the kind of case where wider appellate powers were needed. ${ }^{94}$

There is no known record of applications to the Governor-General under the Criminal Code Act or the Crimes Act 1908. However it appears that few people contesting the validity of a conviction would have been moved to follow the statutory process. Firstly the powers of the Governor General were to grant a pardon or to commute or remit the punishment for an offence. The practical utility of these steps once a penalty had been suffered is doubtful. The pardon might appear as vindication of character, but applications under the section were essentially applications for exercise of the Royal prerogative of mercy. They depended on the assumption that the original conviction had been proper. For those who maintained that the justice system had miscarried and they had been wrongly convicted, the process probably held little attraction.

Nor was there apparently great agitation within the legal profession for any change. While we have no convenient measure of thinking within the profession until the late 1920s, the New Zealand Law Journal would from 1926 have provided a forum for proponents of change. Yet there are only

92 Crimes Amendment Act 1920. The only substantial discussion is reported (30 July 1920) 186 NZPD $885 \mathrm{ff}$.

93 See his concurring judgment in $R v$ Boakes, above $\mathrm{n} 3$, at 458 .

94 The accused was charged with perjury in denying paternity of a child borne to Keyte. During the trial Keyte sat in the court, in clear view of the jury, with a child on her knee dressed similarly to the defendant, and with the child's hair dressed so as to increase the likeness to the defendant. 
two episodes of debate between 1926 and1945. In 1933, the NZLJ twice called editorially for a specialist Court of Criminal Appeal on the English model ${ }^{95}$ and also published a number of solicited comments from leading barristers on the issue. That conspectus indicates there was substantial, but not unanimous, support for some change, principally on the basis that cases would be dealt with much more quickly if there was a specialist court. Several respondents indicated that the English model should be modified by conferring a power to order a re-trial where a conviction was quashed. There was no reference at all to Meikle and other earlier New Zealand cases nor to the debates of the 1900 s.

The second NZLJ piece came only in May $1945,{ }^{96}$ where the editor called for wider appellate powers to deal with cases involving a miscarriage of justice. The timing is interesting. The issue of broader appeal rights had been considered, in a desultory fashion by the Law Reform Committee, made up of officials from relevant ministries between May 1936 and October 1937 but no action was taken. ${ }^{97}$ There is nothing to indicate that word of this debate had reached the ears of the editor. Official debate recommenced in August 1945 quite possibly stimulated by the Law Journal piece of May. With strong backing from the Chief Justice, Sir Michael Myers, ${ }^{98}$ the Attorney-General, Rex Mason introduced a Bill to allow the Court of Appeal to consider appeals on the basis of a miscarriage of justice. ${ }^{99}$ That Bill was broadly supported in Parliament, and quickly passed both Houses.

One interesting feature of the official correspondence and the minuted discussions of the Law Reform Committee in 1936-1937 and in 1945 is the near-total lack of discussion of any New Zealand cases tried before 1920 . The only such case was mentioned by Myers - and neither he nor others ever referred to Chemis, to Meikle or to the debates of 1890-1910.

\section{CONCLUSION}

There is therefore an apparently unexplained gap of 35 years between a period where there was an apparent willingness on the part of Parliament and government to make significant changes to the law relating to criminal appeals, possibly by the creation of a separate court of criminal appeal, and the enactment of substantially broader grounds for appeal. This is the more difficult to explain when

95 "An Opportunity Missed" [1933] NZLJ 17 and "A Court of Criminal Appeal: Further Arguments" [1933] NZLJ 49.

96 "The Necessity for a Court of Criminal Appeal" [1945] NZLJ 113 at 113-118.

97 See documents in "Establishment of a Criminal Court of Appeal 1936-1949" Archives New Zealand, Wellington (ANZ), File J1, Box 1454.

98 Letter from Myers to Mason (4 August 1945) ANZ, File J1, Box 1454.

99 (1 August 1945) 268 NZPD 780. 
there was an obviously successful English model which could have been readily adapted to New Zealand circumstances

It seems very possible that inaction arose from a kind of tacit understanding between politicians, lawyers and judges that the subject of criminal appeals simply should not be ventilated. Why would this be so? Perhaps because there had come to be a perception that any change to the law which made it easier to impugn a conviction on the basis of matters not raised at the trial nor relating to a simple insufficiency of evidence at the trial increase the probability of difficult and divisive - and possibly invalid or unjustified - claims for redress by those who had been convicted. The controversy over Meikle's case might well have generated a concern that increased availability of opportunities for criminal appeals would mean that the state would be called upon to give compensation to the successful appellants. It is striking to compare the views of the Meikle Commissioners on this point with the actual result of the Parliamentary process. The Commissioners were adamant that compensation should only be available where it could be said that the State had caused the miscarriage of justice; the result of the Parliamentary process was the payment of substantial compensation for an act done by a private individual. It may therefore be possible the inertia over reform was a consequence of Meikle's case.

What may have been the result of the long delay in altering the law. Clearly New Zealand criminal jurisprudence was significantly limited because the Court of Appeal was not called on to develop its own body of case law as to what constituted a miscarriage of justice. When that ground was added in 1945, the natural consequence was to look to the English jurisprudence, whether or not that fitted well with the particular provisions of the codified criminal law. Perhaps equally importantly, New Zealand law for several decades failed to provide proper redress for those who had been wrongly convicted. The emphasis on the sanctity of jury verdicts in the face of procedural blemishes must have resonated in the minds of generations of judges and lawyers. If this is so the Meikle case - starting as it did with perjury in a relatively minor criminal case - has had profound if immeasurable effects on New Zealand law. 